\title{
より実りある学術討論の場の構築を目指して 一日本真空学会講演・研究会企画委員会の近年の活動 -
}

\author{
中村 健 $^{1, *}$. 後藤康仁 ${ }^{2}$ \\ 1 産業技術総合研究所 画305-8568 茨城県つくば市梅園 1-1-1つくば中央第二 \\ 2 京都大学大学院工学研究科電子工学専攻 齿 615-8510 京都市西京区京都大学桂 \\ （2017年 11 月 7 日受付；2018 年 3 月 2 日掲載決定）
}

\section{Towards Establishing Our Forum for More Fruitful and Productive Scientific Discussions \\ -Activity Report in Recent Years of the Committee for Scientific Meetings and Symposia, Vacuum Society of Japan-}

Ken NAKAMURA ${ }^{1, *}$ and Yasuhito GotoH ${ }^{2}$

${ }^{1}$ National Institute of Advanced Industrial Science and Technology (AIST),

Tsukuba Central 2, 1-1-1 Umezono, Tsukuba, Ibaraki 305-8568, Japan

${ }^{2}$ Department of Electronic Science and Engineering, Graduate School of Engineering, Kyoto University,

Kyoto-Daigaku-Katsura, Nishikyo-ku, Kyoto 615-8510, Japan

(Received November 7, 2017 ; Accepted March 2, 2018)

\begin{abstract}
The activity of the Committee for Scientific Meetings and Symposia, Vacuum Society of Japan, in the last three years has been summarized, featuring organized sessions and best poster awards at its annual symposia, topical meetings, etc.
\end{abstract}

KEYWORDS : meeting, symposium, organized session, award, discussion

\section{1.は じめに}

日本真空学会と日本表面科学会の合併により, 新たに 公益社団法人日本表面真空学会が誕生することになっ た。母体の一つである日本真空学会は, 1958 年（昭和 33 年) 7 月に「真空技術研究会」と「真空機器協会」の 2 団体が合併して「真空協会」として設立された学術団 体である。設立以降「日本真空協会」(1969 年), 「日本 真空学会」（2012 年）と名称を変更し，またこの間に任 意団体の一般社団法人化（2011 年）等も経て, 真空技 術及びその周辺分野に関わる我が国唯一の学術団体とし て 60 年近い活動を続けてきた。その中で, 2012 年に研 究部会から名称を変更しつつ長い間活動を続けてきたの が講演・研究会企画委員会（以下, 本委員会）である。

*E-mail : ken.nakamura@aist.go.jp
日本真空学会では事業の一つとして「研究発表会・学術 講演会・㦝談会・見学会等の開催」(同学会定款第 4 条) が定められており，これに則して本委員会は「真空に関 する連合講演会等の学術講演会, 研究会, 見学会等を企 画し，新しい学術および技術領域の開拓とその組織化を はかり，この法人の目的の達成に努める」（同学会細則 第 10 条）ことを任務としてきた。特に近年の活動は, 原著論文を中心とした会員の最新の研究報告とそれに関 わる討論の場である「真空に関する連合講演会」の内の 企画の分担と, 特定の具体的な主題に関わる研究の現状 と課題を集中的に討議して最先端の知の体系化を目指す 「研究例会」及び「応用物理学会学術講演会シンポジウ ム」の企画と実施（後者は提案）を中心としてきた。

ところで今般の合併に際しては，本委員会の担当事業 を含めてこれまでの両学会の事業は原則全て継続するこ ととなっている。そこで合併に際する事業移行時期の本 
稿では，主に近年（2015～2017 年度）の本委員会活動 を総括してこれまでの真空学会からの会員のみならず表 面科学会からの会員の皆様とも情報共有を図ると同時 に, そこから運営面でのいくつかの課題を指摘してそれ らに対する方策を提言し，日本表面真空学会に於けるよ り実りある学術討論の場の構築を少し考えてみることと したい。

\section{2. 真空に関する連合講演会}

真空に関する連合講演会は日本真空学会が真空協会と して設立される以前から続く歴史ある学術講演会で, 2017 年開催分で 58 回を数えている。2005 年（第 46 回） 以降は, 本委員会は開催日時・場所の調整等に関わるの みで, 実際はその回毎の「第 X 回真空に関する連合講 演会実行委員会」を組織して運営されてきた ${ }^{11}$ 。招待講 演の選考や 8 分野に分かれての一般講演とポスターセッ ションのプログラム編成などは, 実行委員会众下のプロ グラム委員会が担当してきた。ただし，2015 年より始 まったオーガナイズドセッション（詳細は後述）の公募 ・選考・採択と 1999 年より行われている優秀ポスター 発表の審査と表彰は, 本委員会が責任を持って直接担当 しており, 引き続き連合講演会活性化の維持と向上のお 手伝いをしてきた。

オーガナイズドセッションとは, 2015 年の第 56 回真 空に関する連合講演会より会員の直接的な提案の中から 審査に基づき毎年 1 件ずつ講演会で開催している, 会員 自らが企画（オーガナイズ）する半日の口頭講演セッシ ヨンのことである。これは会員の関心が高いと思われる テーマ及びその研究分野において, 学術情報の交換と新 たな知識の創造の場という学会本来の機能の更なる強化 を意四したもので, 提案資格は日本真空学会会員（個人 会員, 学生会員, 法人会員及び法人会員に属する個人), 日本真空学会の委員会・部会・支部, 及び盟友関係にあ る日本真空工業会としてきた。また提案するオーガナイ ズドセッションの形式は, シンポジウム形式, 通常の口 頭講演セッションと同様に 1 ～2 件の招待講演と一般講 演から成る貸切セッション型, その他の形式 (パネルデ イスカッション，技術報告会など）の何れもが可能であ り, 特にシンポジウム形式はテーマと趣旨の提案のみも 可能として, 提案者の敷居を下げて幅広く提案が得られ るように工夫した。これらを通じて，会員が話したい． 聞きたい・議論したい講演を一つの講演セッションに集 めて講演会を活性化することが狙いである。

2015 年以降これまで毎回 1 件ずつ, 合計 3 件のオー ガナイズドセッションを提案の中から審查によって採択 して開催した（Table 1）。2015 年は後藤康仁会員の提案
Table 1. List of Organized Sessions at the Annual Symposia of the Vacuum Society of Japan from FY 2015 to FY 2017 with their themes, proposers, dates, speakers, and the titles of talks.

$\overline{2015 \sim 2017 \text { 年の「真空に関する連合講演会」オーガナイズ }}$ ドセッション

第 56 回真空に関する連合講演会 $(2015 / 12 / 3$ (木) 午後 $)$

「限界に挑む真空ナノエレクトロニクスの現状と展望」（提案 者 : 後藤康仁)

《特別講演》「真空ナノエレクトロニクスに期待する」三村 秀典（静岡大電子工学研究所）

《特別講演》「シリコンフィールドエミッタからの光支援高 速変調電子ビームの発生」嶋脇秀隆 (八戸工大院工)

《特別講演》「電界放射電子源アレイを用いた超高感度平面 撮像管の開発」難波正和（NHK 技研）

第 57 回真空に関する連合講演会 $(2016 / 11 / 30$ (水) 午後) 「スパッタリング成膜技術の新展開」（提案者：SP 部会（代 表 : 沖村邦雄))

《招待講演》「反応性 HiPIMS プロセスにおけるピーク電流 值による遷移領域制御」清水徹英（首都大東京）

《招待講演》「スパッ夕膜の膜質制御, 高品質化へ向けたア プローチ」加藤和広 (セントラル硝子)

第 58 回真空に関する連合講演会 $(2017 / 8 / 18$ (金) 午後) シンポジウム「真空誌 60 年と学会誌の将来」(提案者 : 編集 委員会 (代表 : 本田融))

第 1 部 真空の科学と技術 : その過去・現在・未来 《依頼講演》「真空誌 60 年 : 後半 30 年に関わって」荒川一 郎(学習院大)

《依頼講演》「真空科学の発展と社会」齊藤芳男（東大）

第 2 部 真空生まれ・真空育ち：新たな科学と技術の足跡を 辿る

《依頼講演》「スピントロニクスデバイス量産用スパッタ成 膜装置」恒川孝二 (キヤノンアネルバ)

《依頼講演》「超高真空下における単原子層物質の物性研究」 有賀哲也（京大）

《依頼講演》「超高真空環境で見えた表面現象」野副尚一 (シエンタオミクロン)

第 3 部 科学技術の進歩と学術雑誌の進化

《依頼講演》「学会誌の将来」久保利隆 (産総研) 総合討論

で, 会期 3 日目である 12 月 3 日（木）午後に従来は複 数のセッションに跨っていたテーマを「限界に挑む真空 ナノエレクトロニクスの現状と展望」と題して集約して 特別講演 (現在の呼称では「招待講演」) 3 件 ${ }^{2 \sim 4)}$ 及び一 般講演 5 件 ${ }^{5,6}$ の 8 件から成る貸切セッション型で開催 された。2016年はスパッタリングおよびプラズマプロ セス技術部会（SP 部会）の提案で, 会期 2 日目である 11 月 30 日 (水) 午後に「スパッタリング成膜技術の新 展開」をテーマに招待講演 2 件 $^{7)}$ 及び一般講演 9 件 $^{8)}$ の 11 件から成る, 前年と同様の貸切セッション型で開催 
された。2017 年は本学会誌の前身の一つである Journal of the Vacuum Society of Japan（通称「真空」）誌の第 60 巻刊行を記念した編集委員会の提案で, 会期 2 日目であ る 8 月 18 日 (金) 午後に「真空誌 60 年と学会誌の将 来」と題して全て依頼講演から成るシンポジウムとして 開催した9)。日本表面科学会及び日本真空学会の合併が 決定した後の開催だったため, 合併後の会誌のあり方に 踏み込んだ議論もあった。この企画には表面科学会の編 集委員会の協力もいただき, 同学会会員の聴講者も多く 見られた。

これらはいずれも, 従来の連合講演会では取り扱いに くいテーマを扱ったものである。口頭講演発表の 8 分野 へのセッション分けは, 関連する研究者の討論の場を集 約するためには必要だが, それですべての講演者・聴講 者にベストのプログラムを提供できるとは限らない。既 存のセッションの範疇に収まりにくい講演が少なくない 場合, 一つの解決策はプログラム委員会の主導で合同セ ッションを編成することだが, いま一つの策は講演を行 う会員の側に主体的に討論の場を構築できる機会を提供 することである。オーガナイズドセッションはそのよう な機会となってきた。ただし今後はフォローアップが必 要であり, 既存の 8 講演分野への講演申込の推移とオー ガナイズドセッションの提案実績を踏まえて, 会員の実 情に合った講演セッションの構成に改めることが求めら れる。ここ数年, 実際の連合講演会は表面科学会の表面 科学学術講演会との合同講演会として開催されてきたが, 日本表面真空学会設立で真に一つの講演会になるため, 講演分野の統合・再編を行うことになる。これをフォロ ーアップの機会と捕らえて, 多くの研究成果を包括・分 類できる講演分野への整理を図って行く必要がある。

連合講演会に於ける本委員会のもう一つの重要な任務 は, 優秀ポスター賞の選考と授与であった。ポスター発 表の表彰は, 1999 年の連合講演会での「優秀ポスター 発表の表彰」に始まり 2017 年まで続いている。当初は 審査の投票権が講演会の参加登録者全員に与えられてお り, 審查への全員参加による講演会との一体感の醸成や 発表者と参加者の討論の促進等, 講演会活性化への一定 の効果が見られた。他方, 係る審查方式は審查基準が審 查員に共有されにくい, その結果審查に公平性や厳正さ が欠けると感じられることに繋がる，等の意見も学会内 から寄せられるようになり, 本委員会でも審査のあり方 について検討を進めてきた。そのため，まず 2010 年及 び 2011 年の連合講演会で本委員会（当時は研究部会） 委員でもある選考委員に所定の票を割り当てて, 一般参 加者による投票傾向との比較が行われた。その結果を踏 まえて, 2012 年より審査を本委員会が指名する審査委
員が参加者を代表して行うこととした。また，審查対象 となる発表者の年齢を, 講演会開催年の 4 月 1 日で 40 歳未満と明確化した。その後, 2015 年より名称を「優 秀ポスター発表の表彰」から「優秀ポスター賞」に改め ている。

Table 2 に, 近年の優秀ポスター賞受賞者とその共著 者及び講演題目を示す。プラズマ科学技術, 応用表面科 学, 真空科学技術 ${ }^{100}$, 表面科学 ( 2 件) 等, 多様な講演 分野のポスター発表が表彰されていることがわかる。ポ スター発表の表彰が始まって 20 年近くが経ち表彰され た方も 40 名を超えたが, 若手会員の研究への動機付け と登竜門としての役割は十分に果たしてきたと言えよ う。受賞者の皆さんの益々の活躍に期待すると同時に, 今後も若手の研究活動奨励のために, 日本表面科学会の 講演奨励賞と合わせて新学会の講演会での優秀な若手発 表者の表彰制度を維持・改善していく検討が進められて いる。

講演会の活性化と参加者の一体感釀成を狙って始まっ た優秀ポスター表彰は，若手会員の育成と奨励に成果を 挙げた。したがって, 発表者にも質問者にも時間の縛り

Table 2. List of Poster Award winners at the Annual Symposia of the Vacuum Society of Japan from FY 2015 to FY 2017 with their titles and names of coauthors.

2015 2017 年の「真空に関する連合講演会」優秀ポスター 賞（下線が受賞者）

第 56 回真空に関する連合講演会 $(2015 / 12 / 1$ (火) 12/3 (木))

1P12V「反応性スパッタにおけるモード遷移挙動の普遍性」

$\bigcirc$ 木村光作 ${ }^{1)}$, 竹内将人 ${ }^{1)}$, 飯嶋佑斗 ${ }^{1)}$, 長尾昌善 ${ }^{2)}$, 大崎 壽 ${ }^{2}$, 中野武雄 ${ }^{1)}$ (1) 成蹊大院理工, 2) 産総研)

2P62V「ダイヤモンド PIN ダイオード型電子源からの電子放 出」

$\bigcirc$ 松本 翼 ${ }^{1,4)}$, 門脇 良 $^{2)}$, 加藤宙光 ${ }^{1), 4)}$, 牧野俊晴1,4), 竹内大輔 ${ }^{1), 4)}$, 河野省三 ${ }^{3)}$, 虬川匡司 ${ }^{2)}$, 山崎 聡(1),4) (1) 産 総研，2）東北大多元研，3）早大理工，4）CREST/JST)

第 57 回真空に関する連合講演会 $(2016 / 11 / 29$ (火) 12/1(木))

1PA11V「分子交換流を用いた混合気体の分離実験」

$\bigcirc$ 松本理彰, 杉元 宏 (京大院工)

2PB05V「Verwey 転位温度前後でのマグネタイトの X 線光電 子磁気円二色性」

$\bigcirc$ 橋本由介, 松井文彦, 田口宗孝, 松田博之, 深見 駿, 田中一光, 岡本隆志, 米田允俊, 大門 寛 (奈良先端大物 質創成）

第 58 回真空に関する連合講演会 $(2017 / 8 / 17$ (木) 8/19 (土))

2P12V「アナターゼ $\mathrm{TiO}_{2}(101)$ 表面に吸着した $\mathrm{CO}_{2}$ の大増強 赤外吸収」

$\bigcirc$ 山川紘一郎 ${ }^{1,2)}$, 長塚直樹 ${ }^{2)}$, 小倉正平 ${ }^{2)}$, 福谷克之 ${ }^{2)}$ (1) 学習院大理, 2) 東大生研) 
が少ないポスター発表を講演会の活性化に積極的に活か す次の策を講じる時期に来ている。例えば，ポスター 発表件数が増えると, 数多くのポスターの中から自分 の興味あるポスターへ到着し説明を聞き議論する時間 の十分な確保が難しくなる。ショートプレゼンテーショ ンの導入やポスター掲示時間の長時間化は, その対策 として有効だろう。本学会主催の国際会議 International Symposium on Sputtering and Plasma Processes (ISSP) の 様に口頭講演者もポスター発表する方法も, 議論を深め る機会として参考になる ${ }^{11)}$ 。内外の学会では, 大型ディ スプレイを使ったデジタルポスターとでもいうようなポ スターセッションも増えているようだ。研究して打く価 值はあるだろう。またポスター会場では展示会も開催し ているが，ポスターセッション時間帯以外には集客がよ くないとの声も聞かれる。会場の余裕にもよるが, オー プンスペースを活かした産学連携セッション等も開催で きるだろう。講演では難しいより直接的な学術交流の場 として, ポスター会場は発展性を秘めた空間である。

\section{3. 研究例会など}

連合講演会を原著論文とすると, 研究例会 ${ }^{12}$ は総説・ 解説論文である。1958 年 (昭和 33 年) 9 月の第 1 回研究 例会に始まり, 2017 年度中に開催回数が通算 203 回に 達する実績を重ねてきた。近年の研究例会の主題等を Table 3 に示す。 1 回の研究例会に午後の半日を充てて, その中で 5 件程度の招待講演を聴くのが通例となってい る。ただし，より多くの講演を依頼したり，そのために 午前中から開催することもあり, 臨機応変にプログラム 編成を行っている。研究例会は年 4 回開催しており, そ のうち 3 回は真空, 表面, または薄膜関係の何れかを主 題に企画されて東京近辺で開催される。そこで本委員会 に在籍している 20 名の委員を真空班・表面班・薄膜班 の 3 班に分け, 定例の委員会終了後の班別検討会議や日 常のメールベースでの検討作業を通じて企画をまとめて きた。ただし研究例会の主題の区分と班別を厳格に対応 させることはせずに, 班別の議論の結果主題が融合的に なることはむしろ良しとしてきた。な打表面を主題とし た研究例会は表面科学会の表面科学研究会との合同研究 例会としており, 2018 年 1 月研究例会が先方の第 90 回 表面科学研究会に対応している。近年の主題は, 真空班 担当分が低・中真空計測 ${ }^{13 \sim 18)}$, フィルム, 極低温 ${ }^{19}$, 表 面班担当分がトライボロジー（表面科学会が企画主担 当), 光とセンシング20), 光電子分光 (表面科学会が企 画主担当), 薄膜班担当分がナノカーボン, 原子層成長 (ALD)，金属造形 21 等となっている。

テーマを絞った研究例会の参加者は平均すると 50 名
Table 3. List of Topical Meetings of the Vacuum Society of Japan from FY 2015 to FY 2017 with their themes, dates, venues, and numbers of participants. No description on the meeting venue indicates that it was held at Kikai-ShinkoKaikan Bldg in Shiba-Koen, Minato-ku, Tokyo.

2015 2017 年度の日本真空学会研究例会

- 「低真空・中真空計測の最新動向」2015/6/9 (火) 85 名

・「プラズマ励起プロセスを用いた表面改質の基礎と応用」 2015/11/17 (火) (広島工業大学広島校舎) 22 名

・「カーボン系新材料研究の現状と展望」2015/12/16 (水) 23 名

・「ナノトライボロジー : 現在と未来」2016/1/22 (金)（東 京大学理学部化学館 (化学本館) 5 階講堂; 日本表面科学 会第 87 回表面科学研究会及び第 3 回関東支部セミナーを 兼社る) 82 名。

-「真空を用いたフィルム加工技術」2016/7/11（月）50名

-「真空と水・表面と水：身近な物質の物理と化学」2016/ 10/6（木）（北海道大学学術交流会館；日本表面科学会 2016 年東北・北海道支部研究会を兼视る）15名

-「真空中での原子層成長：ALD 技術の最近の進歩」2016/ $12 / 14$ (水) 98 名

・「光と表面：バイオセンシング・ガスセンシングへの応 用」2017/1/18 (水) (日本表面科学会第 89 回表面科学研 究会及び第 6 回関東支部セミナーを兼ねる) 30 名

-「真空技術と極低温技術」2017/6/23 (金) 36 名

-「真空技術が切り拓く光・電子・プラズマの最先端」 2017/9/26 (火) (愛媛大学工学部) 70 名

- 「金属積層造形技術の現状と展開」2017/12/5 (火) 24 名

-「硬 $\mathbf{X}$ 線光電子分光の産業利用への展開と将来展望」 2018/1/18（木）（東京理科大学森戸記念館；日本表面科 学会第 90 回表面科学研究会及び第 8 回関東支部セミナー を兼ねる) 35 名

程度だが，いたずらに人数を増やすことは例会の趣旨と は相容れないので, この程度の参加人数での開催を定例 としてきた。ただし研究例会運営上の基盤碓保も必要な ため, 2016 年度より参加費を若干值上げさせていただ いた。しかし参加人数に目立った影響は見られなかった ので, 会員の皆様にはご理解いただいたものと感謝して いる。また媣堀の議論ができるように, 連合講演会等に 比べて充実した内容の予稿原稿を講演者の先生方には抄 願いしている。そのため, 後日それらを発展させた解説 記事をご執筆いただき, 編集委員会の主導で小特集が会 誌に企画されたことも少なくない。参加できなかった会 員からは好評である。そのようなことから, 学会内の他 の委員会・部会・支部等の企画担当者間での各企画に関 する情報共有は重要である。これは企画の重複を避ける ためにも必要である。合併で日本表面真空学会になると 規模が拡大して事業の数も増えるので, 今後も情報共有 をより一層確実に図る必要性には留意しておきたい。ま た学会外への効果的な広報活動も引き続き重要な課題で ある。近年は趣旨に賛同いただける他学会から協賛をい 
ただくことで, 当該学会の同学の士に対して開催する研 究例会をご案内してきたが, 今後は平行してホームペー ジにおける新学会の広報活動と連携したより直接的な情 報発信にも戦略的に取り組む必要がある。

年 4 回の研究例会のうち 1 回は，東京以外の地に抢邪 魔して地元の先生方の協力の下で開催する地方研究例会 である。1998 年以来毎年開催されており， 2013 年の SPring-8 (兵庫県佐用町), 2014 年の東北大学片平キャ ンパス（仙台市青葉区）に続いて，2015 年は 11 月 17 日（火）に広島工業大学広島校舎（広島市）に於いて 「プラズマ励起プロセスを用いた表面改質の基礎と応 用」 ${ }^{22 \sim 24)}$ に関して，2016 年は 10 月 6 日（木）に北海道 大学学術交流会館（札幌市）で「真空と水・表面と水： 身近な物質の物理と化学」 ${ }^{25 ~ 27) を テ ー マ に し て, ~} 2017$ 年は 9 月 26 日（火）に愛媛大学（愛媛県松山市）に て「真空技術が切り拓く光・電子・プラズマの最先 端」 ${ }^{28)}$ を主題に開催した。な打表面科学会東北・北海道 支部のご好意で共同開催とさせていただいた札棍研究例 会は, 2022 年の当地での 22nd International Vacuum Congress（IVC-22）開催決定 ${ }^{29}$ の 1カ月半後だったので, 齊藤芳男真空学会会長（当時）と岡本鉄男日本真空工業 会専務理事 (当時) も出席し, その翌日には来札した荻 野俊郎表面科学会会長（当時）が合流して IVC-22 会場 予定施設を視察した。

近年の地方研究例会では, いくつかの新しい試みを行 った。2015 年の広島研究例会では, 例会の主題に関わ らず一般講演のポスターセッションを「2015 年真空に 関する研究発表会」として併催し, 真空が関わる科学技 術全般の最新の研究成果を発表する場を提供した。通常 の研究例会中頃の $10 \sim 15$ 分程度の休悡時間を 45 分程 度に拡大して，ポスターセッションに充てたものであ る。2015 年の「真空に関する連合講演会」が茨城県つ くば市での開催だったため, 遠隔となる広島をはじめ西 日本の会員・協賛学会員に便宜を供したものでもあり, 5 件の研究発表と 2 件の研究機関の事業紹介の展示があ った。2017 年の松山研究例会では, 研究例会当日の午 前中に真空技術入門講座「真空技術の基礎と応用」を開 講し, 愛媛大学の学生さんを中心に 50 名の受講者を得 て, 大変好評だった ${ }^{28)}$ 。

学会の催事は, 基本的に本部事務局のある東京周辺あ るいは支部の事務局機能がある特定の地域での開催に偏 りがちである。例えばこれまでの連合講演会は東京及び その近郊と関西での隔年開催が慣例化しており, 2008 年の島根県松江市と 2016 年の名古屋市での開催が数少 ない例外であった。1998 年以降の 20 回の地方研究例会 (北海道 2 回, 東北 4 回, 中部 6 回（うち名古屋市 3
回), 関西 1 回, 中国・四国 5 回, 九州 2 回）は, これ らの課題を補完してきたと言える。特に中部地方（特に 名古屋市）での研究例会の開催実績は, 日本真空学会東 海支部設立の基盤として貢献させていただけたと思う。 合併後の日本表面真空学会では，これまでの真空学会会 員は国内いずれかの支部に所属するので, 講演会・研究 会の開催に各地域の声がより大きく反映することが期待 される。その中での本部企画の地方研究例会は，支部間 や支部と本部各委員会・部会との連携企画等，これまで の経験を踏まえつつ新たな学術交流の企画を実現する機 会と捉えたい。

最後に, 本委員会では応用物理学会春季学術講演会シ ンポジゥム ${ }^{30)}$ の企画・提案も行ってきたので, 触れてお く。これは, 2012 年春季までは応用物理学関係連合講 演会として日本真空学会を含む幾つかの学会の共同開催 だったため, 本委員会企画のシンポジウムを例年開催し ていたことに由来する。近年では，本委員会の企画を応 用物理学会 (応物) 会員でもある本委員会委員と応物の プログラム編集委員が共同で世話人になり応物薄膜・表 面分科の分科企画シンポジウムとして提案し，採択後に 開催してきた ${ }^{31)}$ (Table 4)。

応物春季学術講演会全体は例年 7,000 人程度の参加が ある ${ }^{32,33)}$ ので，シンポジゥムにも通常の研究例会に比べ て多くの聴采が集まる。当該シンポジウムに限った参加 登録は行わないため正確な数字は不明だが, 会場への出 入りを含めると例年延べ 100 名近い参加者が聴講してい ると見積もられる。個別技術の専門学会から総合学会会 員への情報発信として, 真空とその周辺領域の研究成果 と今後の課題をより幅広い聴衆に提起できる, 大変よい 機会となっている。また研究例会に参加して下さる応物 会員の方々も少なくない。これらを鑑みて, 日本表面真 空学会は応用物理学会と引き続き連携を図り梁めていく ことが重要と考えている。

Table 4. List of vacuum-related symposia at the spring meetings of the Japan Society of Applied Physics from 2016 to 2018 with their themes, dates, and venues. 


\section{4.お おりに}

以上, 日本真空学会講演・研究会企画委員会の近年の 活動を報告するとともに，これらを踏まえた運営面での 課題のいくつか (講演会とセッション分類, ポスターセ ッションの活性化, 研究例会の展開, 地方での活動のあ り方, 他学会との交流）を指摘して, 今後の対策に係る 提言を試みた。2018 年には, 日本真空学会と日本表面 科学会が合併して新たに日本表面真空学会が誕生する。 しかし冒頭で述べたとおり, 細部の調整は必要であるも のの, 原則として個々の事業は継続するので, 今後の講 演会・研究会の企画について新学会会員の皆様からの忌 憚のないご意見を引き続きお寄せいただきたい。また事 業を運営する組織・体制は, 講演会担当, 研究会担当及 び表彰担当の委員会を別々に設置する方向で調整が進ん でいる。事業運営をより効率的に進められるように努め たいと考えている。

\section{謝 辞}

これまでの活動は, 全て本委員会委員各位との共同作 業の成果である。2015～2017 年度の 3 年間は, 委員長 を中村（2015～2016 年度，2017 年度は委員）及び後藤 （2017 年度以降）が, 副委員長を関口信一（荏原製作 所，2017 年度以降，2015 2016 年度は委員）及び高橋 直樹（アトナープ, 2015 年度以降）の両氏が務め, 委 員として荒川一郎 (学習院大), 板倉明子 (物材機構), 上野啓司 (埼玉大), 上原孝浩 (大阪真空), 大岩烈 (シ エンタオミクロン), 加藤茂樹 (高エネ研), 久保敦 (筑 波大), 佐々木正洋 (筑波大), 鈴木僚 (富士通研), 早 田康成 (日立中研), 高橋茂樹 (サムスン日本研, 〜 2015/7), 谷本育律 (高エネ研, ～2017/3), 土佐正弘 (物材機構), 中村恵 (キヤノンアネルバ), 福谷克之 (東大生研, ～2017/3), 前重和伸 (旭硝子), 守山佳彦 (東芝), 吉田肇 (産総研), 吉浜知之（アルバック, 2015/11～）の各位にご尽力いただいた。また地方研究 例会開催に際しては, 田中武 (広島工大), 豊田宏（広 島工大), 小池正記 (広島工大), 朝倉清高 (北大), 島 田敏宏（北大）, 石川史太郎（愛媛大）の各先生に, 表 面科学会との合同研究例会開催には本間芳和（東京理科 大), 山本貴博 (東京理科大), 河野禎市郎 (旭化成), 町田雅武（シエンタオミクロン）の各先生及び日本表面 科学会摩擦の科学研究部会の諸先生方に多大なご協力を いただいた。これらの皆様方に感謝の意を表したい。あ りがとうございました。

\section{文献}

1) K. Nakamura : J. Vac. Soc. Jpn. 60, 519 (2017). (Report)

2) H. Mimura : J. Vac. Soc. Jpn. 60, 2 (2017).

3) H. Shimawaki : J. Vac. Soc. Jpn. 60, 8 (2017).

4) M. Nanba : J. Vac. Soc. Jpn. 60, 18 (2017).

5) S. Horie, K. Asanagi, T. Myojin, T. Higuchi, Y. Yamada and M. Sasaki : J. Vac. Soc. Jpn. 60, 13 (2017).

6) M. Nagao : J. Vac. Soc. Jpn. 59, 108 (2016).

7) T. Shimizu, M. Villamayor, J. Keraudy, D. Lundin and U. Helmersson : J. Vac. Soc. Jpn. 60, 346 (2017).

8) M. Kuroiwa and T. Nakatani : J. Vac. Soc. Jpn. 60, 372 (2017).

9) N. Nakamura : Vac. Surf. Sci. 61, 181 (2018). (Report)

10) M. Matsumoto and H. Sugimoto : J. Vac. Soc. Jpn. 60, 142 (2017).

11) K. Okimura : Vac. Surf. Sci. 61, 88 (2018).

12) The Vacuum Society of Japan, http://www.vacuum-jp. org/eventetc/host/kenkyureikai (Last accessed : 201711-07)

13) H. Yoshida : J. Vac. Soc. 59, 237 (2016).

14) H. Miyashita, H. Onuma, Y. Ide, I. Mochizuki and N. Saito : J. Vac. Soc. 59, 255 (2016).

15) Y. Yoshikawa : J. Vac. Soc. 59, 259 (2016).

16) Y. Takamiya : J. Vac. Soc. 59, 239 (2016).

17) N. Ohsako and M. Kuroiwa : J. Vac. Soc. Jpn. 60, 193 (2017).

18) T. Hori, H. Yoshizawa and T. Tanaka : J. Vac. Soc. Jpn. 60, 182 (2017).

19) A.N. Itakura : J. Vac. Soc. Jpn. 60, 410 (2017). (Report)

20) T. Yamamoto and Y. Homma : J. Surf. Sci. Soc. Jpn. 38, 313 (2017). (Report)

21) R. Suzuki : Vac. Surf. Sci., to be published. (Report)

22) S. Higashi : J. Vac. Soc. Jpn. 60, 77 (2017).

23) H. Toyota : J. Vac. Soc. Jpn. 60, 81 (2017).

24) N. Terayama : J. Vac. Soc. Jpn. 60, 85 (2017).

25) Y. Kunisada : J. Vac. Soc. Jpn. 60, 249 (2017).

26) K. Yamakawa : J. Vac. Soc. Jpn. 60, 256 (2017).

27) T. Hama, A. Kouchi and N. Watanabe : J. Vac. Soc. Jpn. 60, 264 (2017).

28) F. Ishikawa : Vac. Surf. Sci. 61, 98 (2018). (Report)

29) K. Fukutani, Y. Saito, Y. Tanimoto and S. Hasegawa : J. Vac. Soc. Jpn. 60, 24 (2017).

30) The Japan Society of Applied Physics https://www. jsap.or.jp/activities/annualmeetings/index.html (Last accessed : 2017-11-07)

31) The Vacuum Society of Japan http://www.vacuum-jp. org/応用物理学会春季学術講演会 (Last accessed : 2017-11-07)

32) Editorial Committee : Oyo Buturi 85, 267 (2016).

33) Editorial Committee : Oyo Buturi 86, 278 (2017). 